\title{
Remagnetizations in Late Permian and Early Triassic rocks from southern Africa and their implications for Pangea reconstructions
}

\author{
Martha M. Ballard ${ }^{1}$, Rob Van der Voo ${ }^{1}$ and I.W. Hälbich ${ }^{2}$ \\ ' Department of Geological Sciences, University of Michigan, Ann Arbor, MI 48109 (U.S.A.) \\ 2Department of Geology, University of Stellenbosch, Stellenbosch (Republic of South Africa)
}

Received March 31, 1985; revised version received June 24, 1986

\begin{abstract}
A paleomagnetic study of late Paleozoic and early Mesozoic sedimentary rocks from southern Africa suggests wide-spread remagnetization of these rocks. Samples of the Mofdiahogolo Formation in Botswana and of the Lower Beaufort Group in South Africa were treated using thermal, alternating field and chemical demagnetization. The Mofdiahogolo redbeds show a univectoral decay of the remanence revealing a characteristic direction of $D=340^{\circ}$, $I=-58^{\circ}, k=64, \alpha_{95}=12^{\circ}$. The Lower Beaufort sandstones, using thermal and alternating field demagnetization, show a very similar direction of $D=337^{\circ}, I=-63^{\circ}, k=91, \alpha_{95}=6^{\circ}$. A fold test on the Beaufort rocks is negative indicating that this magnetization is secondary and acquired after the Permo-Triassic Cape Belt folding event. Previous studies have reported similar directions in the. Upper Beaufort redbeds as well as in the Kenyan Maji ya Chumvi Formation of Early Triassic age. The poles of these studies have been used in testing the validity of the various Pangea reconstructions for the Late Permian and the Early Triassic. Our results suggest that these poles may also be based on remagnetized data and that their use to document the position of Gondwana in Pangea reconstructions should be treated with caution.
\end{abstract}

\section{Introduction}

Paleomagnetic data indicate that the Wegener fit, or Pangea A as it has come to be known, while probably valid for the earliest Jurassic, is not supported by the paleopoles for late Paleozoic and Early Triassic time [1]. Several alternative preJurassic reconstructions have been proposed. Pangae A2 [2] fits northwestern South America tightly into the present day Gulf of Mexico and juxtaposes northwest Africa against the eastern U.S. seaboard. This is achieved by rotating Gondwana $20^{\circ}$ clockwise about a pole in the Sahara relative to the Wegener fit [3]. Pangea $B$, proposed by Irving [4], requires a $35^{\circ}$ clockwise rotation of Gondwana relative to Laurasia. This places northwestern South America against the eastern U.S. seaboard and Africa somewhere south of the Balkans. Pangea A2 agrees well with Carboniferous and Early Permian paleomagnetic data while the Late Permian and Early Triassic data are in better agreement with Pangea B [1].

Thus, paleomagnetic data cannot at present eliminate either reconstruction. However, the data base for the Late Permian and the Early Triassic is small and, more importantly, the ages of the magnetic directions for these rocks arc not well-constrained. The present paleomagnetic study of the folded Late Permian Lower Beaufort Group from the Karoo Basin in southern Africa serves to test the validity of the previously published poles for this same time period.

\section{Geology}

The Cape Fold Belt is part of a Gondwana-wide orogen that is preserved in South America, southern Africa, Antarctica and Australia. In southern Africa, the deformation style is predominantly one of east-west trending major folds that verge to the north (Fig. 1b). Although metamorphic grade increases gradually southward up to the lowermost greenschist facies, the fold intensity may change abruptly across the trend to produce a zoned orogen. This is also reflected in two types of Pan African basement underlying the Cape Fold Belt as inferred from geophysical studies of the region. An east-west trending highly conductive crustal 

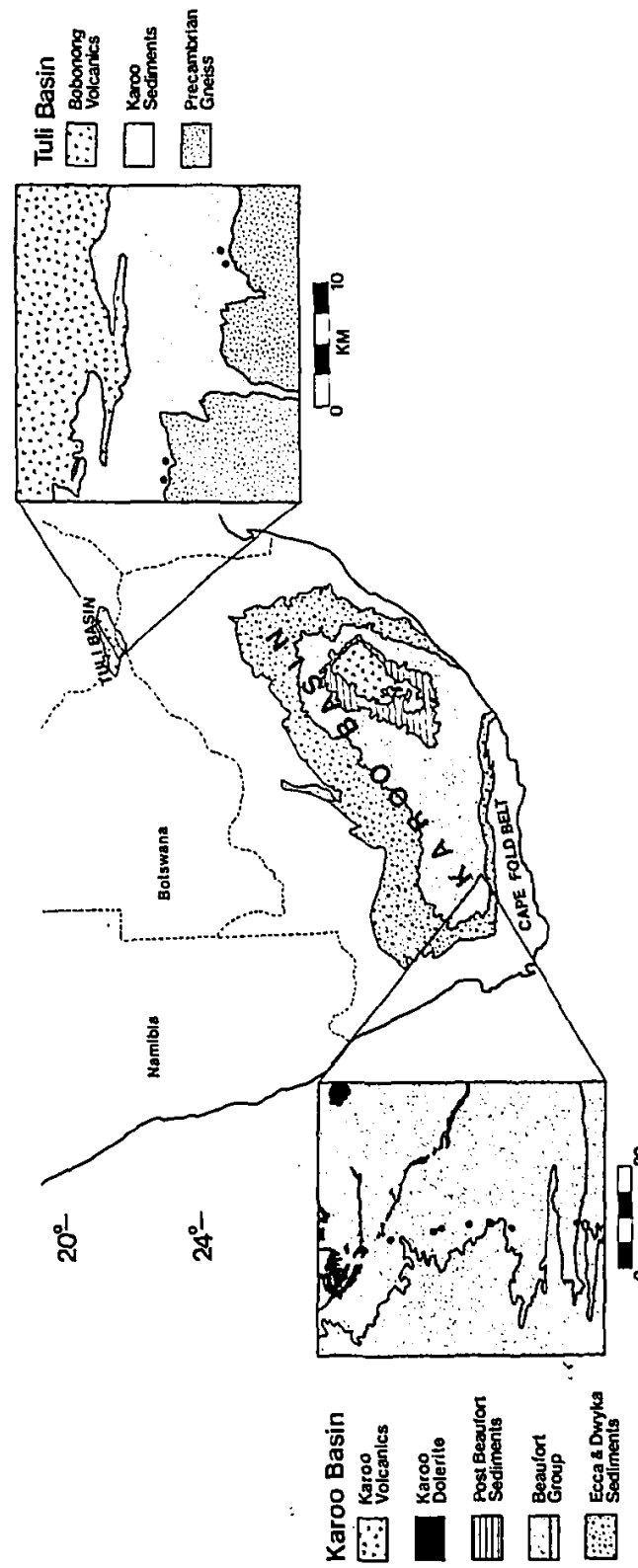

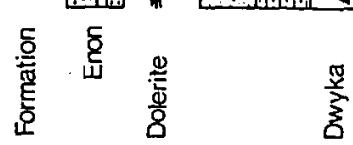

ริ

瞽

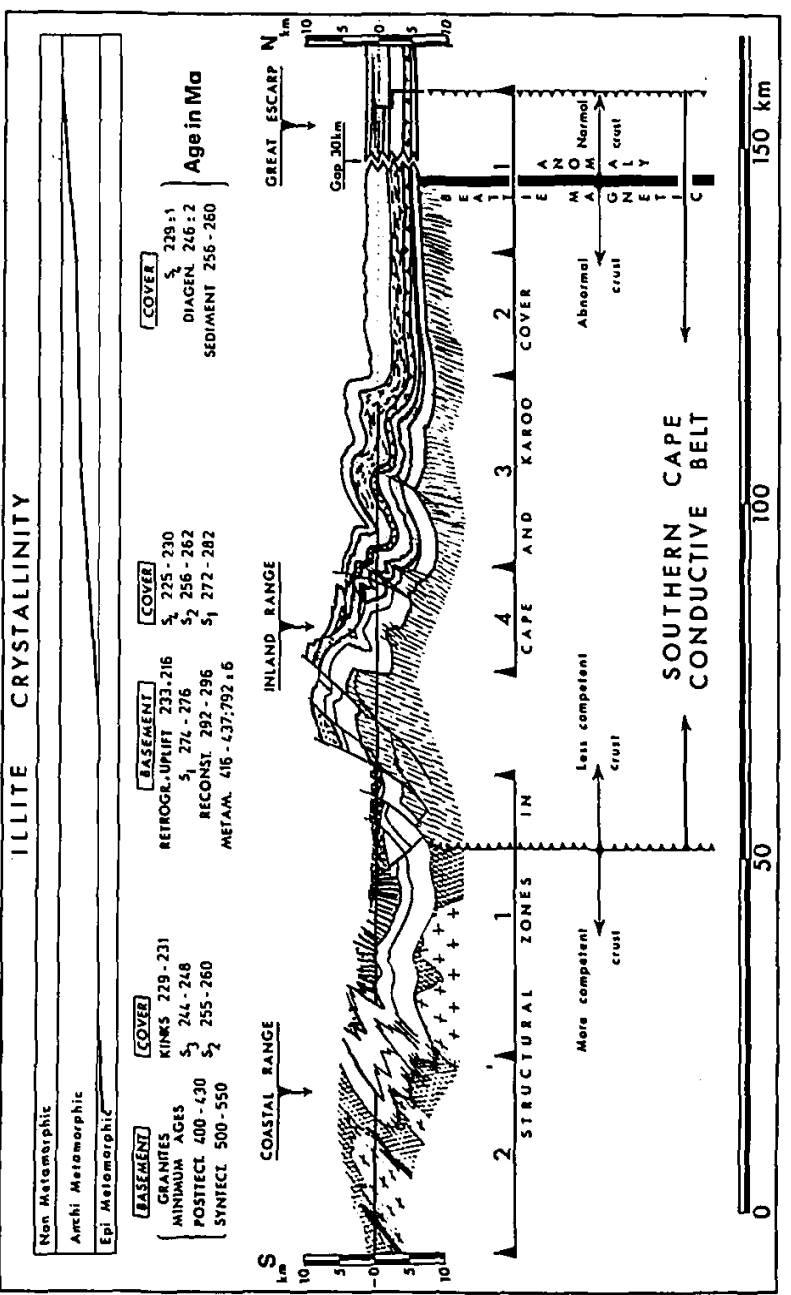

a

造

in

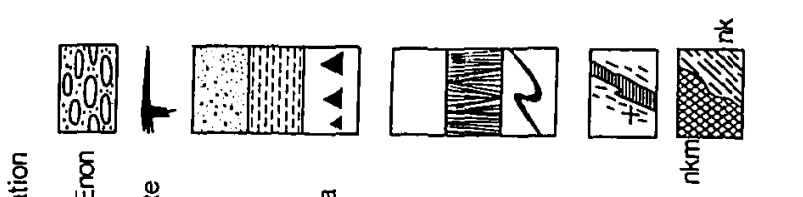

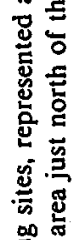

疍

을 蛋

青

营

品:

官 总

5 这

岕焉涭

○ิ 造

峞泀

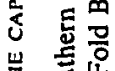

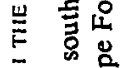

흥

를

乙

氮

席 8

资

U

造

됼

은

¿

品全吉

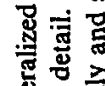

要

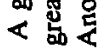

․․․․․

$\rightarrow$ o

棺兽焉 
segment today underlies the north-central zone of the fold belt and its basement (Fig. 1b). The northern boundary of the segment at about $32^{\circ} 45^{\prime} \mathrm{S}$ along $22^{\circ} 30^{\prime} \mathrm{E}$ coincides with the Beattie magnetic anomaly [5]. De Beer et al. [6] interpret this segment as weak, heavy crust that located the axial zones of the Cape and Karoo Basins and, during the Cape orogeny, helped to control tectonic movements in time and space.

The available evidence for the Cape folding points to a short-lived intra-cratonic orogenic episode [7]. The conspicuous absence of synorogenic magmatic activity has also been explained by a flat-plate subduction model which positions a subduction zone $\approx 1000 \mathrm{~km}$ to the south of the Cape Fold Belt [8], Hälbich et al. [9] interpret the Cape folding as a semi-continuous deformation with four compressive pulses that began in the Early Permian (278 Ma), with concomitant Ecca Group deposition in the Karoo Basin that developed north of the rising mountain chain. A climax was reached in the middle Permian (258 Ma) with the beginning of Beaufort sedimentation. The third (247 Ma-latest Permian) and fourth (230 MaLate Triassic) orogenic pulses were synchronous with the deposition of the Upper Beaufort beds and higher Karoo strata respectively.

Underlain by Permo-Carboniferous glaciogenic deposits (Dwyka Formation) and a thick sequence of Permian clastic deposits ranging from starved basin muds and turbidites (Ecca Group) that grade upward to fluvial channel facies, the Beaufort Group is made of alternating layers of gray/green sands and reddish mudstones becoming coarsergrained higher in the section. Smith [10] interprets these deposits as channel and flood basin facies which probably developed in front of the rising Cape orogen to the south.

The occurrence of Endothiodon and Cistecephalus [11] ties the age of the Lower Beaufort to the latest Permian/earliest Triassic. The results of ${ }^{39} \mathrm{Ar} /{ }^{40} \mathrm{Ar}$ age dating of the Lower Beaufort rocks [9] suggest that the Lower Beaufort was subsequently deformed during the fourth pulse of the Cape folding event, $230 \mathrm{Ma}$ ago. In the central part of the Karoo Basin, the Beaufort Group is intruded by Karoo dolerite sheets and dykes, dated from 159 to $190 \mathrm{Ma}$ [12].

Thirty-seven hand samples from seven sites were collected in the Lower Beaufort along a south- north traverse from gently folded rocks nearer the Cape orogen toward the undeformed, horizontal strata further north (Fig. 1a).

Karoo deposits are also found in the partially fault-bounded Tuli Basin in eastern-central Botswana (see Fig. 1a). These deposits include the undeformed mudstones of the Mofdiahogolo Formation, which are interbedded with more arenaceous layers and a few ironstones [13] and lie uncomformably on Precambrian gneissic basement. These are unconformably overlain by coarse clastics which have been correlated with the Seswe Formation. The Seswe Formation, in turn, is interpreted as the successional equivalent of the Fulton's Drift Mudstones found in the continuation of the Tuli Basin into Zimbabwe where Glossopteris, Phyllotheca and Calamites have been found [14]. On this basis, a Late Permian age has been assigned to the Mofdiahogolo Formation. Capping the entire sedimentary section is a series of subaerial basalts, the Bobonong Lava Formation, with a $\mathrm{K} / \mathrm{Ar}$ age of $181 \pm 4 \mathrm{Ma}$ [15]. Limestones intercalated in the lavas are assigned an Early Jurassic age based on palynomorphologic study [15]. Fig. 1 shows the locations of four sites from which fourteen hand-samples were taken from the basal mudstones.

\section{Laboratory techniques}

Remanent magnetizations of all the samples collected were measured using either a Superconducting Technology (ScT) cryogenic magnetometer or a Schönstedt SSM-1A spinner magnetometer. To isolate the characteristic magnetic directions, several stepwise demagnetization techniques were used. Thermal demagnetizations were done in a Schönstedt TSD-1 model oven. A Schönstedt GSD-1 AC Specimen Demagnetizer was used for alternating field (AF) demagnetizations. Chemical demagnetizations were performed by leaching vertically notched samples in $8 \mathrm{~N} \mathrm{HCl}$ while in a reduced magnetic field space.

The magnetic direction remaining after each treatment was plotted using the demagnetization diagrams described by Zijderveld [16]. Characteristic magnetic directions were, in all cases, determined by principal component analysis [17]. 


\section{Results}

All fourteen mudstone samples collected in Botswana possessed a north-northwesterly and steeply up natural remanent magnetization (NRM). Due to the high coercivity of the magnetic carriers, AF demagnetization was ineffective in cleaning these rocks. Samples from this collection were treated with either thermal or chemical step-wise demagnetization techniques. With both techniques, the magnetic remanence decayed linearly to the origin (Fig. 2a, b). Samples that were more red in color exhibited maximum blocking temperatures of $660-685^{\circ} \mathrm{C}$, characteristic of hematite. However, these samples lost up to one half of their original intensity at blocking temper-
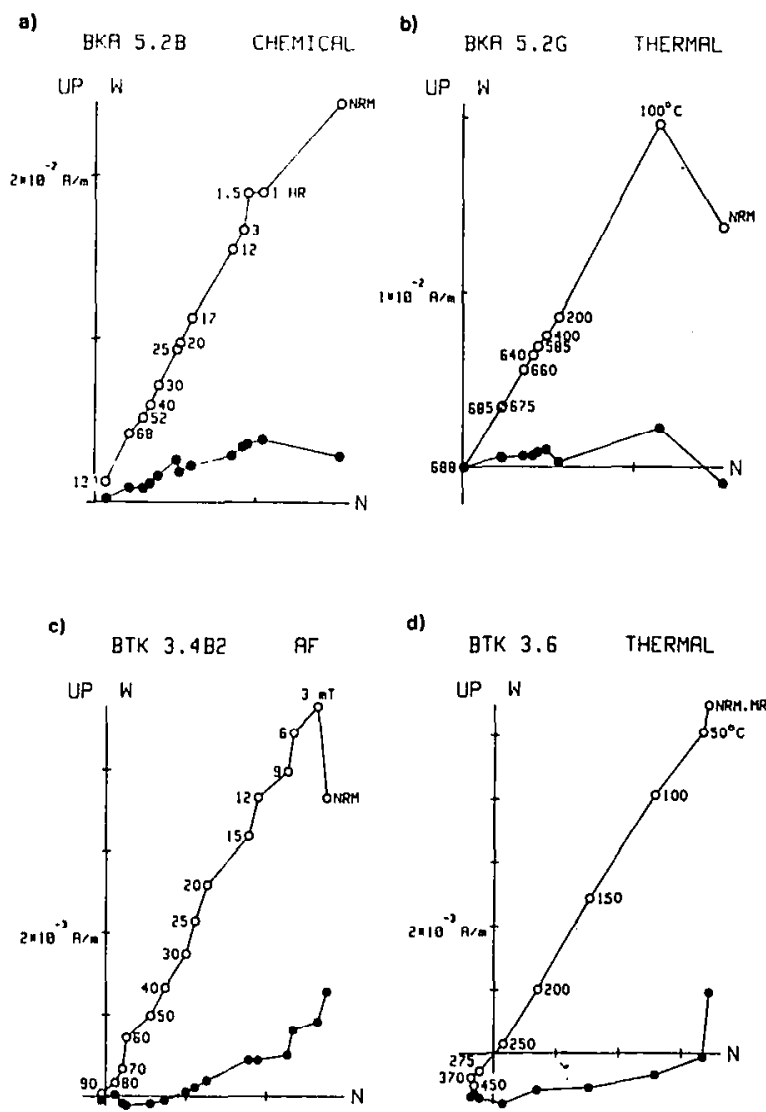

Fig. 2. Representative demagnetization diagrams [13]. Open (closed) circles represent projections onto a vertical (horizontal) plane. (a) Chemical and (b) thermal demagnetizations of samples from Botswana. (c) AF and (d) thermal demagnetizations of Beaufort samples. atures less than $350^{\circ} \mathrm{C}$. In the remainder of the samples, the characteristic magnetization was almost completely eliminated at temperatures below $350^{\circ} \mathrm{C}$. Chemical demagnetization revealed a similar, univectoral decay of the remanence.

The mean characteristic magnetization for all fourteen samples is $D=340^{\circ}$ and $I=-58^{\circ}$. Sample directions are averaged in Table 1 and plotted in Fig. 3b.

NRM directions for the Lower Beaufort are all north-northwesterly and steeply up. In AF demagnetization, these rocks appeared to contain a single component of magnetization with a north-northwesterly declination and a steeply up inclination. This component was completely removed by 90 mT (see Fig. 2c).

Thermal demagnetization (Fig. $2 \mathrm{~d}$ ) revealed a low-blocking temperature $\left(50-350^{\circ} \mathrm{C}\right)$ component that was identical to the directions found using AF demagnetization and similar to the direction isolated in the Botswana rocks. However, the trajectories bypass the origin suggesting that at least one other component of magnetization exists

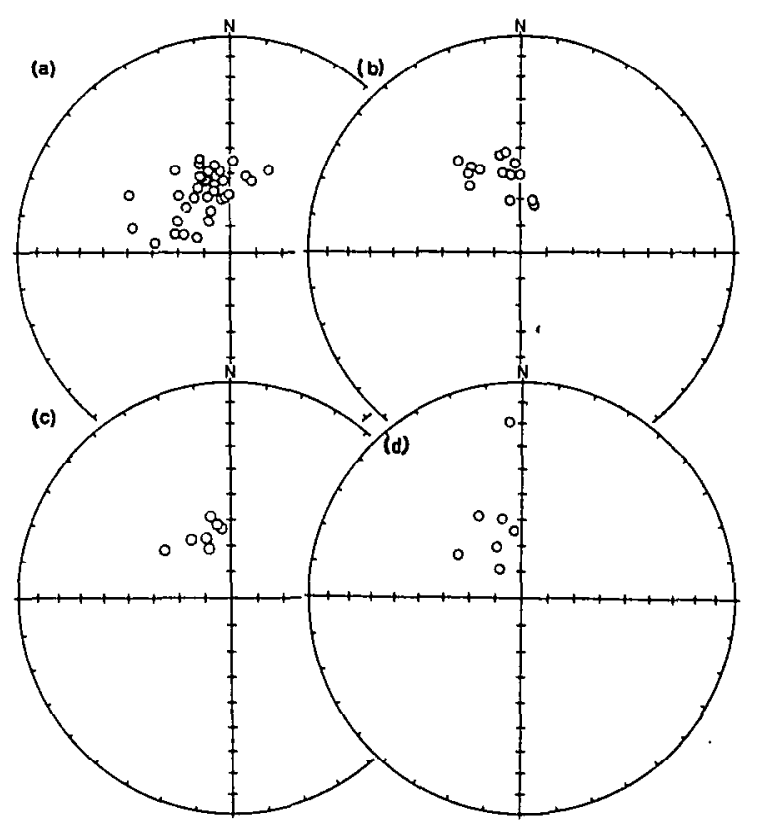

Fig. 3. Equal area plots obtained from demagnetization analysis of (a) sample directions found in Beaufort samples, (b) sample directions found in samples from Botswana, (c) site mean directions in Beaufort samples before tilt correction, (d) site mean directions in Beaufort samples after tilt correction. Open circles are upper hemisphere projections. 
TABLE 1

\begin{tabular}{|c|c|c|c|c|c|c|c|c|}
\hline \multirow[t]{2}{*}{ Site } & \multirow[t]{2}{*}{ Location } & \multirow[t]{2}{*}{$n$} & \multicolumn{3}{|c|}{ Uncorrected } & \multicolumn{3}{|l|}{ Corrected } \\
\hline & & & $D / I$ & $k$ & $\overline{\alpha_{95}}$ & $\overline{D / I}$ & $k$ & $\overline{\alpha_{95}}$ \\
\hline \multicolumn{9}{|c|}{ Mofdiahogolo Formation } \\
\hline 1 & $28^{\circ} 15^{\prime} \mathrm{E}, 22^{\circ} 10^{\prime} \mathrm{S}$ & 3 & $336 /-54$ & 153 & 10 & $336 /-54$ & 153 & 10 \\
\hline 2 & $28^{\circ} 15^{\prime} \mathrm{E}, 22^{\circ} 10^{\prime} \mathrm{S}$ & 2 & $325 /-53$ & 127 & 23 & $325 /-53$ & 127 & 23 \\
\hline 3 & $28^{\circ} 25^{\prime}$ E. $22^{\circ} 10^{\prime} \mathrm{S}$ & 3 & $346 /-54$ & 76 & 14 & $346 /-54$ & 76 & 14 \\
\hline 4 & $28^{\circ} 25^{\prime} \mathrm{E}, 22^{\circ} 10^{\prime} \mathrm{S}$ & 6 & $358 /-65$ & 130 & 6 & $358 /-65$ & 130 & 6 \\
\hline \multicolumn{2}{|c|}{ Formation mean } & 14 & $340 /-58$ & 64 & 12 & $340 /-58$ & 64 & 12 \\
\hline \multicolumn{9}{|c|}{ Lower Beaufort Group } \\
\hline 1 & $22^{\circ} 30^{\prime} \mathrm{E}, 32^{\circ} 30^{\prime} \mathrm{S}$ & 7 & $338 /-65$ & 176 & 5 & $335 /-68$ & 174 & 5 \\
\hline 2 & $22^{\circ} 30^{\prime} \mathrm{E}, 32^{\circ} 30^{\prime} \mathrm{S}$ & 4 & $337 /-69$ & 60 & 12 & $328 /-76$ & 59 & 12 \\
\hline 3 & $22^{\circ} 30^{\prime} \mathrm{E}, 32^{\circ} 32^{\prime} \mathrm{S}$ & 7 & $347 /-58$ & 232 & 4 & $347 /-58$ & 232 & 4 \\
\hline 4 & $22^{\circ} 30^{\prime} \mathrm{E}, 32^{\circ} 25^{\prime} \mathrm{S}$ & 4 & $307 /-59$ & 24 & 19 & $304 /-60$ & 24 & 19 \\
\hline 5 & $22^{\circ} 30^{\prime} \mathrm{E}, 32^{\circ} 35^{\prime} \mathrm{S}$ & 6 & $354 /-63$ & 19 & 16 & $354 /-63$ & 19 & 16 \\
\hline 6 & $22^{\circ} 30^{\prime} \mathrm{E}, 32^{\circ} 37^{\prime} \mathrm{S}$ & 6 & $326 /-63$ & 33 & 12 & $332 /-54$ & 31 & 12 \\
\hline 7 & $22^{\circ} 30^{\prime} \mathrm{E}, 32^{\circ} 45^{\prime} \mathrm{S}$ & 3 & $350 /-61$ & 23 & 26 & $357 /-19$ & 23 & 27 \\
\hline \multicolumn{2}{|c|}{ Formation mean } & 37 & $337 /-63$ & 91 & 6 & $340 /-59$ & 16 & 16 \\
\hline
\end{tabular}

$D=$ magnetic declination, degrees; $l=$ magnetic inclination, degrees; $k=$ precision parameter; $\alpha_{95}=$ confidence interval, degrees.

in these rocks. In the next section, we will discuss our analysis of the remaining remanence.

For the first removed components the sample directions are averaged in Table 1 and plotted in Fig. 3a. The Lower Beaufort is gently folded with fold limbs dipping up to $40^{\circ}$ in the southerly sites enabling us to use a fold test in order to date the acquisition of magnetization relative to the age of folding. In situ, the site-mean characteristic directions from both thermal and AF demagnetization cluster very well about a mean of $D=337^{\circ}, I=$ $-63^{\circ}$ (Fig. 3c). After unfolding, the clustering sharply deteriorates (Fig. 3d); the precision parameter, $k$, decreases from $91\left(k_{1}\right)$, to $16\left(k_{2}\right)$. Similarly $\alpha_{95}$ increases after unfolding from $6^{\circ}$ to $16^{\circ}$. The fold test is negative, significant at the $99 \%$ confidence level, indicating that this magnetization was acquired sometime after these sediments were folded, i.e. after about $230 \mathrm{Ma}$.

\section{Great circle analysis: Lower Beaufort Group}

At higher temperatures, the magnetization of the Lower Beaufort samples often becomes unstable due to the growth of new iron oxides, making it impossible to identify the direction of the highblocking temperature component of magnetization. Following Halls [18], we have fitted remagne- tization circles to the Lower Beaufort data in an attempt to determine this magnetic direction. Fig. 4 shows that the intersection of those great circles in field coordinates is superior to the intersection in bedding coordinates. The intersection in both coordinates is parallel to the directional axis determined from the first removed directions of Fig. 3.

Thus, we are unable to determine any but the

POLES TO GREAT CIRCLES

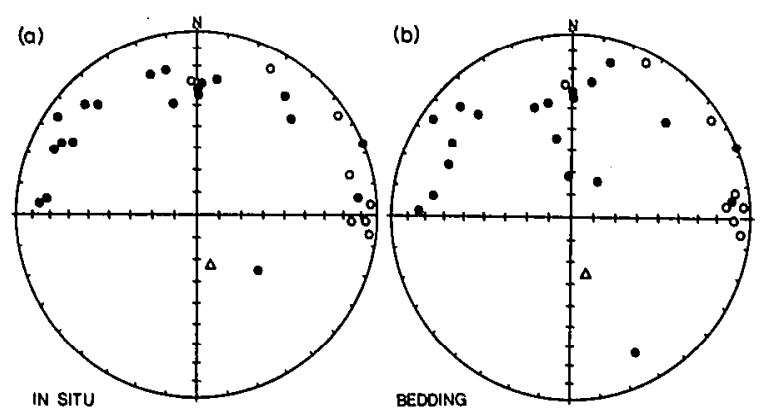

Fig. 4. Poles (normals) to remagnetization great circles for the Beaufort samples plotted on lower hemisphere equal area projections. Open (closed) symbols are upper (lower) hemisphere projections, (a) before bedding correction and (b) after bedding correction. The mean direction removed common to all samples is shown as an open triangle. 
post-folding direction using great circle analysis. Nevertheless, we have reconfirmed the secondary nature of the north-northwest and steeply up direction.

\section{Discussion}

Our results from the Lower Beaufort Group and the Mofdiahogolo Formation clearly show the secondary nature of the magnetization. Paleopoles based on these directions plot at $68^{\circ} \mathrm{E}, 61^{\circ} \mathrm{S}$ and $70^{\circ} \mathrm{E}, 66^{\circ} \mathrm{S}$ respectively. Two other paleomagnetic studies that have been conducted on African rocks of Early to Middle Triassic age are of interest here. McEllinny and Brock [19] studied the Early Triassic Maji ya Chumvi sandstones found in Kenya. Similar to the Lower Beaufort results, the bulk of the magnetic remanence of these flat-lying rocks was removed below $350^{\circ} \mathrm{C}$. The resulting paleopole position is $69^{\circ} \mathrm{E}, 67^{\circ} \mathrm{S}$.

Graham [20] conducted a study of the Upper Beaufort Group redbeds exposed in the eastern part of the Karoo Basin. The Upper Beaufort, believed to be of Middle Triassic age [21] was found to be extremely stably magnetized when subjected to alternating fields of up to $55 \mathrm{mT}$. No other demagnetization techniques were used. A paleopole of $87.1^{\circ} \mathrm{E}, 67.1^{\circ} \mathrm{S}$ was determined in that study.

In both of the above mentioned studies, it was not possible to perform any of the standard paleomagnetic tests used to date the acquisition of magnetization, i.e. a fold test, conglomerate test, or baked contact test. In addition, all the samples in both studies displayed magnetizations of normal polarity. As a result, the age of the magnetization cannot conclusively be constrained; there is no upper limit to the possible age of magnetization.

Our results from the Lower Beaufort Group and the Botswana Mofdiahogolo Formation studies indicate that both contain secondary or postfolding magnetizations. The magnetizations were acquired sometime after the Lower Beaufort was folded in the Triassic.

In Fig. 5, the paleopoles from all four formations discussed in this paper are plotted. The clustering of these poles suggests that the magnetizations were all acquired at the same time. We have shown in this study that the Lower Beaufort

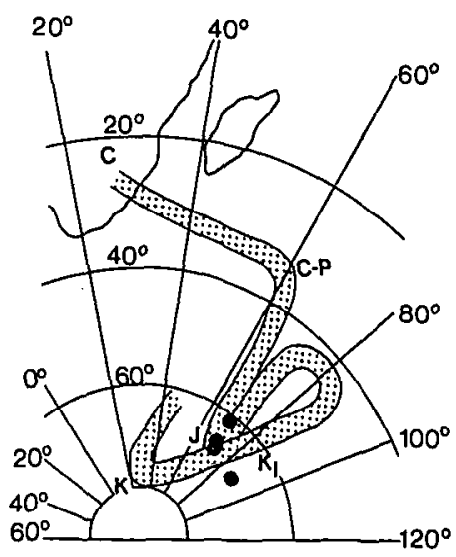

Fig. 5. Poles from this study, Zijderveld [16] and Kirschvink [17], superimposed on the African apparent polar wander path for the Carboniferous through the Cretaceous [22]. $C, C-P, J$, $K_{1}, K$ represent Carboniferous, Permo-Carboniferous, Late Triassic/Jurassic, Early Cretaceous and late Early/Late Cretaceous paleopole positions respectively.

pole is based on a post-folding magnetization. Although the other studies do not have similar tests, we suggest that all these poles are based on directions derived from rocks that have been remagnetized.

The timing of this remagnetization event is uncertain but, by comparing these southern African poles to a previously published apparent polar wander path (APWP) for Africa [22], we find that these poles fall very close to the Jurassic portion of the APWP. There are numerous and extensive Jurassic intrusives and extrusives in southern Africa which have been associated with the breakup of Pangea. In many cases, these igneous rocks (e.g. Karoo dolerites, Bobonong lavas) are proximal to the rocks used in the paleomagnetic studies. The inferred wide-spread remagnetizations may be related to these igneous rocks.

The results of this study indicate that many of the available Late Permian/Early Triassic paleomagnetic data from southern Africa do not represent the Late Permian/Early Triassic geomagnetic field for this time period and, therefore, cannot be used to test the validity of any Pangea reconstruction for this time period. The removal of the Upper Beaufort Group and the Maji ya Chumvi poles from the reliable southern African paleomagnetic data base leaves only the pole from 
the Cassanje series, Angola [23] for this time period. In addition, paleomagnetic data from South America for the late Early Permian to the Middle Jurassic define a quasi-static period [24]. These data, therefore, are not likely to be suitable for documenting the relative position of the southem continents for the time immediately preceding the Pangea A fit. This implies that we must postpone a re-evaluation of the validity, with regard to paleomagnetic data, of the two Pangea reconstructions (A2 and B) at least for Late Permian and Early Triassic time.

On the other hand, and as previously noted, Pangea A2 has the statistically superior fit in terms of the Late Carboniferous and Early Permian paleomagnetic data. It was already known that the paleomagnetic data base for the Late Permian/Early Triassic was very limited. But now that we have shown that many of these data represent remagnetizations, we must conclude that the paleomagnetic data for the Late Permian and Early Triassic are insufficient to make any choices among alternative Pangea reconstructions.

\section{Acknowledgements}

We thank Dr. Valerian Bachtadse for his helpful comments and Sanford Ballard III for his unflagging support throughout this project. We would also like to thank Johan Swart and Dr. Isaac Rust and colleagues for their invaluable assistance. The manuscript has benifitted greatly from reviews by R.B. Hargraves and R.G. Gordon. This study has been supported by grants from Sigma Xi, Turner Fund, the J.T. Wilson Fund, a Departmental grant from SOHIO Corp. and the Division of Earth Sciences, the National Science Foundation, grant EAR 84-070079.

\section{References}

1 R. Van der Voo, J. Peinado and C.R. Scotese, A paleomagnetic reevaluation of Pangea reconstructions, in: Plate Reconstructions from Paleozoic Paleomagnetism, $\mathbf{R}$. Van der Voo, C.R. Scotese and N. Bonhommet, eds., Geodyn. Ser. 12, 11-26, 1984.

2 R. Van der Voo and R.B. French, Apparent polar wandering for the Atlantic-bordering continents: Late Carboniferous to Eocene, Earth Sci. Rev. 10, 99-119, 1974.

3 E.C. Bullard, J.E. Everett and A.G. Smith, A symposium on continental drift-IV. The fit of the continents around the Atlantic, Philos. Trans. R. Soc. 258, 41-45, 1965.

4 E. Irving, Drift of the major continental blocks since the Devonian, Nature 270, 304-309, 1977.
5 J.H. De Beer, Geophysical studies in the southern Cape Province and models of the lithosphere in the Cape Fold Belt, Spec. Publ. Geol. Soc. S. Afr. 12, 57-64, 1983.

6 J.H. De Beer, J.S.V. Van Zijl and D.I. Gough, The Southern Cape Conductive Belt: its composition, origin and tectonic significance, Tectonophysics 83, 205-225, 1982.

7 I.W. Hälbich, A geodynamic model for the Cape Fold Belt, Spec. Publ. Geol. Soc. S. Afr. 12, 177-184, 1983.

8 B.E. Lock, Flat plate subduction and the Cape Fold Belt of South Africa, Geology 8, 35-39, 1980.

9 I.W. Hälbich, F.J. Fitch and J.A. Miller, Dating the Cape orogeny, Spec. Publ. Geol. Soc. S. Afr. 12, 149-164, 1983.

10 R.M.H. Smith, Sedimentology and taphonomy of lower Beaufort floodplain deposits, Geol. Soc. S. Afr., 18th Congr., Abstr. 2, 136-144, 1979.

11 South African Committee for Stratigraphy (SACS), Stratigraphy of South Africa, 1. Lithostratigraphy of the Republic of South Africa, Southwest Africa/Namibia, and the Republics of Bophuthatswana, Transkei and Venda, L.E. Kent, compiler, Handb. Geol. Surv. S. Afr. 8, 1980.

12 I. McDougall, Potassium-argon age measurements on dolerites from Antarctica and South Africa, J. Geophys. Res. 68, 1535-1545, 1963.

13 G.C. Clark and T.P. Machacha, The geology of the Baines Drift area, Botswana Geol. Surv. Bull. 19,65 pp., 1982.

14 R.A. Smith, The lithostratigraphy of the Karoo Supergroup in Botswana, Geol. Surv. Dep. Botswana Bull. 26, 239 pp., 1984.

15 D.T. Aldiss, J.M. Benson and C.C. Rundle, Early Jurassic pillow lavas and palynomorphs in the Karoo of eastern Botswana, Nature 310, 302-304, 1984.

16 J.D.A. Zijderveld, A.C. demagnetization of rocks: analysis of results, in: Methods in Paleomagnetism, D.W. Collinson, K.M. Creer and S.K. Runcorn, eds., pp. 245-286, Elsevier, Amsterdam 1967.

17 J.L. Kirschvink, The least-squares line and plane and analysis for paleomagnetic data, Geophys. J.R. Astron. Soc. 45, 699-718, 1980.

18 H.C. Halls, A least-squares method to find a remanence direction from converging remagnetization circles, Geophys. J.R. Astron. Soc. 45, 297-304, 1976.

19 M.W. McElhinny and A. Brock, A new paleomagnetic result from East Africa and estimates of the Mesozoic paleoradius, Earth Planet. Sci. Lett. 27, 321-328, 1975.

20 K.W.T. Graham, Paleomagnetic studies on some South African rocks, 140 pp., Ph.D. Thesis, University of Cape Town, 1961 (unpublished).

21 J.M. Anderson and A.R.I. Cruickshank, The biostratigraphy of the Permian and the Triassic Paleontol. Afr. 21, 15-44, 1978.

22 D.A. Valencio, J.F. Vilas and I.G. Pacca, The significance of the paleomagnetism of Jurassic-Cretaceous rocks from South America: pre-drift movements, hairpins and magnetostratigraphy, Geophys. J.R. Astron. Soc. 73, 135-151, 1983.

23 D.A. Valencio, A.C. Rocha-Campos and I.G. Pacca, Paleomagnetism of the Casange series (Karoo system), Angola, An. Acad. Brasil. Cienc. 50, 353-364, 1978.

24 D.A. Valencio and J.F.A. Vilas, Palaeomagnetism of Late Paleozoic and Early Mesozoic rocks of South America, Earth Planet. Sci. Lett. 15, 75-85, 1972. 